\title{
Fluorine 18 F Fludarabine
}

National Cancer Institute

\section{Source}

National Cancer Institute. Fluorine 18 F Fludarabine. NCI Thesaurus. Code C115978.

A radiopharmaceutical containing the purine analog fludarabine that is labeled with the radioisotope fluorine $\mathrm{F} 18$ with potential use as a tumor imaging agent upon positron emission tomography (PET). After intravenous administration, the fludarabine is selectively taken up by tumor cells. The radioisotope moiety is detected using PET, which allows imaging and quantification of both the biodistribution of fludarabine and the presence of tumor cells. This could identify tumors and select patients that will likely respond to fludarabine treatment. 